\title{
Aging With Disney and the Gendering of Evil
}

\author{
Nada Ramadan Elnahla \\ Alexandria University, Alexandria, Egypt
}

\begin{abstract}
Walt Disney animated films are considered synonymous with wholesome family entertainment despite the inherent negative messages of gender, age, and power hierarchies behind them. This paper proposes to explore the aspect of age as intersecting with gender through the villainesses in six of Disney’s popular animated films: Snow White and the Seven Dwarfs (1937), Cinderella (1950), Sleeping Beauty (1959), The Little Mermaid (1989), Tangled (2010), and Frozen (2013). How Disney alters the actions of major and minor characters, and the construction of aging female characters and the key characteristics they exhibit during their fight for eternal youth, beauty, and social and political power will be analyzed, attempting to show how Disney is not a harmless substitute for a babysitter for children.
\end{abstract}

Keywords: aging, ageism, feminism, Disney, animated films, villain

\section{Introduction}

In 1923, Walt Disney and his brother Roy pooled their money to set up a cartoon studio in Hollywood: The Disney Brothers' Studio. It would take Disney 14 years before the first animated feature-length version of Snow White was released. The film's phenomenal success at the time (earning eight million dollars on its initial release and winning a full-size Oscar statuette and seven miniature ones) signaled the beginning of a golden age of animation and a rising influence of the Disney movies, brand, and theme parks. By the mid-1970s, Disney studies started growing, fed by "legions of Disneyfied baby boomers", encompassing various interdisciplinary areas including: media studies, anthropology, sociology, psychology, economics and business practices, international studies tracking the global positioning of colonial outposts, cultural studies, feminism, race, and gender (Doherty, 2006). However, the aspect of age as intersecting with gender needs to be added and will be, therefore, addressed in this paper. Disney's animated films are an international cultural icon that, especially lately, could be considered a force in raising the consciousness of societies, by depicting our inhumanity from the perspective of other species, for example, empowering bookworm characters (Beauty and the Beast) and women leaders (Pocahontas, Mulan), and presenting us with handicapped and ethnic outcast heroes (The Hunchback of Notre Dame). Nevertheless, and although Disney has the capacity to alter consciousness about growing older, it has failed in transcending the prejudices against female aging characters. Older women are either "backgrounded as loving (preferably deceased) mothers or, if powerful and independent, vilified as evil femme fatales or ugly hags" (Wohlwend, 2009, p. 59). Such a blend of sexism and ageism will be traced through the villainesses in six of Disney's popular animated films, analyzing the construction of aging female characters and the key characteristics they exhibit. The chosen films are: Snow White and the Seven Dwarfs (1937), Cinderella (1950), Sleeping Beauty (1959), The Little Mermaid (1989), Tangled (2010), and Frozen (2013).

Nada Ramadan Elnahla, Ph.D., lecturer, Department of English, Faculty of Arts, Alexandria University. 


\section{The Concept of Aging}

A central concept when discussing age is the meaning of age itself, for to identify it, one has to not only acknowledge chronological age — or the years since birth—but also to pay attention to its various social and psychological dimensions (Moody, 2006, p. 2). The words “aging”, “elder”, “old”, and "old age” are some of the most emotionally charged and ambiguous words in language. Historically, aging has been exclusively viewed in terms of physical deterioration, gerontologists, however, have drawn our attention to the various spectrums of age:

chronological age (the numerical total of years lived), biological age (the strength, health, vigor, and elasticity of the body, which frequently bear little relationship to chronological age), social age (the culturally constructed, often prescriptive behaviours arbitrarily linked to a chronological numeral), and individual age (our own self-image, which is often at variance with all the other markers of age. (Deats \& Lenker, 1999, p. 9)

However, such markers of age are not always in synchrony, for there could be wide disparities between them.

The term "ageism" was first coined in the late 60s in the United States by Robert Butler to name widespread discrimination against the elderly solely based on their being "old". Butler argued that ageism is rooted largely in Man's fear of death and that the denial of ageing characterizes our culture. Despite the works of feminist writers like Simone de Beauvoir, whose canonical work La Vieillesse (The Coming of Age) first appeared in 1970, and Susan Sontag, who discussed the double marginality experienced by women who are older as early as 1972, older women still experienced invisibility. One of the reasons behind this invisibility could be the fact that Second Wave feminism focused on and reflected the concerns of younger women, for example, reproductive rights, child care, and the right to enter certain domains of work. In addition, female attractiveness has long been associated with youth, and the older woman has been thought of in disparaging terms as "menopausal" and "post-menopausal", hence, aging casting its shadow on women earlier than on men. Thus, "women usually experience aging by the age of 50, internalizing the culture's denial of and distaste for ageing, understanding it in terms of decline and not in terms of growth and change” (Woodwind, 1999, pp. $\mathrm{x}$-xiii). Nowadays, and as a result of ingesting nutritional supplements and testosterone or human growth hormones, the increase in the number of hours people spend at the gym, undergoing cosmetic surgery, and using creams, lotions, and hair dyes to erase the physical markers of age, the "equation of old age with disease and physical and mental decline is so prevalent that visible signs of aging serve to justify the limitation of the rights and authority of old people” (Calasanti, Slevin, \& King, 2006). American fitness guru Tony Horton is well known for constantly claiming that "aging is for idiots" (Luscombe, 2012). Thus, whoever lives long enough will face age oppression (Calasanti et al., 2006, p. 25).

A close consideration of the impact of old age and the concept of aging should be part and parcel of the analysis of art, and literature in general, for to ignore this aspect of a character's life experience is to ignore a fundamental part of human nature. In order to deconstruct the negative stereotypes of aging one encounters, gerontologists advocate the understanding that there is a construction of stereotypic images of aging; literature, the arts and the media not only mirror the conventional mores and attitudes of their societies, but they also create them. To Moody (2006), "The image of old age purveyed by mass media has a profound effect on attitudes toward aging in all industrialized societies" (p. 3). Thus, "old” is not defined by bodily changes, but by beliefs, customs, traditions, and the meanings given to those changes (Cruikshank, 2009, p. 6). For women to 
comfortably age, there should be an awareness of and a resistance to social constructions; we need to "imagine what aging would be like once we free ourselves from the negative beliefs about it”; we need to learn to be old (p. ix).

One of the great benefits of aging is the freedom to reclaim the buried aspects of the self, for example, women can start exploring their assertive, commanding or adventurous previously repressed personalities, and attributes traditionally gendered "masculine”, and shifting the balance of gender power (Deats \& Lenker, 1999, p. 5). However, the way mass media presents aging influences the viewers' perception, and when that portrayal of the aging female is by Disney's animations, then the influence is even greater, for Walt Disney Productions it is considered to be synonymous with wholesome family entertainment in the global marketplace, enjoyable by children of all ages (Hannon, 1997). Unfortunately, many Disney works create negative cultural icons, for example, "female villainesses who exhibited many of the negative stereotypes of aging" (Perry, 1999, p. 203), bartering everything for the sake of eternal youth, beauty, and social and political power. Since culture mirrors society, some of Disney's full-length animated films reflect societies' double standard concerning aging.

\section{Snow White and the Seven Dwarfs}

Originated in the oral Germanic tradition and adapted from one of Grimm's fairy tales, Snow White narrates the story of an aging woman who will stop at nothing to forever become the fairest of them all. Obsessed with aging and her physical appearance, the "evil queen" dresses her daughter-in-law in rags and forces her to work as a scullery maid while daily asking her mirror "Magic mirror on the wall, who is the fairest one of all?" and a rephrase of Grimm's text is :

Tell me, glass, tell me true!

Of all the ladies in the land,

Who is fairest, tell me, who?

Although the Brothers Grimm version is based on a "medieval conception of power as a matter of physical force” (Booker, 2010, p. 4), the film depicts the queen's power as a matter of subtle psychological manipulation. The queen's employment of the mirror could be interpreted as a classic case of the doppelganger, a protagonist whose fatal mistake is her inability to secure her identity by disavowing her other self, unleashing it as an uncontrollable monster-self. In the case of the evil queen, consequently, her obsession with power and physical beauty becomes her downfall. Another dehumanizing technique is not providing the queen's character with a specific name. In the Disney film, she is identified as the "evil queen”, the "wicked queen”, the "wicked witch", the "old hag" or just simply "queen" or "witch". In other films and TV interpretations, she is sometimes called "Queen Grimhilde” (Disney publications of the 1930s), "Queen Chrystal” (The Legend of Snow White, 1994), "Elspeth” (Snow White: The Fairest of Them All, 2001), "Lady Vain” (Happily N'Ever After 2, 2009), “Queen Regina” (Once Upon a Time, 2011), “Queen Gwendolyn” (Grimm's Snow White, 2012), “Queen Clementiana” (Mirror, Mirror, 2012), and "Queen Ravenna” (Snow White and the Huntsman, 2012). Thus, by simply calling her the "queen", Disney strips her of the remnants of her humanity, leaving the audience with the adjectives "evil”, “wicked”, and “old”, hence, indirectly equating wickedness with ageism.

One method of evaluating the body, which increases the sense of competition and insecurity in women, is physical body comparisons (Hesse-Biber, 1997, p. 70), for example, when Snow White's grace can no more be hidden by rags, the queen tries to destroy the former. What she does firstly is ordering the henchman to murder her, secondly, by pulling her lace too tightly (this scheme is found only in the fairy tale version), thirdly, by 
presenting her with a poisoned comb (again, a detail only found in the fairy tale), and fourthly, by disguising herself as an old peddler and feeding Snow White a poisoned apple. Thought dead by her friends, the seven dwarfs, Snow White is laid in a coffin made of glass, foiling the queen's plans by not burying the young woman alive, for like many American in the first half of the 20th century, the dwarfs were fixated on the beautiful body, "too entranced by it to say goodbye forever" (Laderman, 2000, p. 42). The dwarfs' decision to put the young princess in a glass coffin (rather than a wooden one), turning her into an object of display, therefore, reveals their vanity, echoing the queen's vain tendencies. In Grimm's fairy tale, Snow Drop is saved when a prince falls in love with her apparently dead, yet pretty, body and while moving her coffin, the poisoned apple falls from between her lips, waking her up. As for the evil queen, she literally chokes to death with rage. In Disney's film, the queen falls from a cliff and dies after poisoning Snow White and, opposite to the fairy tale, the prince who has been searching for her high and low, awakens her with a kiss (a favored sexist theme by Disney for many years, yet slightly better than the original necrophilic theme). Finally, the dreams of Snow white, a house-proud beauty, come true; the story ends with the promise of domestic bliss, a ray of hope in an uncertain malevolent world (Laderman, 2000, p. 43) when they ride away together on a gallant steep, Snow White riding demurely sidesaddle. Such “contamination” of the traditional fairytale material could be seen in other aspects of the film. According to Deszez (2002),

In the Grimm's version of the tale, there can be discerned symbols and notions relating to a life-and-death power struggle, jealousy, rivalry and oppression, whereas the cartoon reinforces the conviction that individuals should accept their position and unquestionably carry out their duties. This subliminal message is evoked through spotlighting the figures of the hard-working, orderly and diligent Seven Dwarfs, who in the literary version are actually of minor importance. (p. 86)

Similar to the case of Cinderella, the adult viewer should question what children learn from what could be perceived as a problematic and disturbing ending. Solis (2007) argues that “even though the Queen [is] vilified, children might learn that being just beautiful is not as good as being the most beautiful, and that attempting to become the most beautiful is worth taking risks, and even worth dying for" (p. 120). Moreover, what if Snow White were not beautiful enough? Would she have been buried alive and no one would have desired to rescue her? Her weaknesses as a female, furthermore, are evident in her relationship with the seven dwarfs. Although on the surface it appears that she is the motherly figure who takes care of them, in reality, by cooking, cleaning, washing, sewing, knitting, and taking care of the dwarfs, she becomes a caretaker of men in exchange for protection. When she does not honor their wisdom and knowledge-opening the door to strangers though she is instructed not to-she is punished and lies comatose, showing that disobeying men have severe ramifications. Yet, it takes a real man, the prince, to save Snow White (Solis, 2007, p. 123).

From the beginning of the tale, the queen is portrayed as a lonely old woman ("old" here is more of a social age, for it is only perceived in light of Snow White's much younger age). Without a husband or traditional loving relations, she only has a black-crow for company. Her age and fading beauty make her a personification of evil. By presenting her as the "other”, exaggerating her differences and overlooking shared characteristics, Disney distances the queen, creating emotional distance between her and the viewers. She fits Cruikshank's definition of how an old woman becomes "an alien creature, costly and crabby, and her life stage is seen as disconnected from youth and midlife rather than as an outgrowth of them” (Cruikshank, 2009, p. 5). The link between old age and villainy is taken a step further when the queen is in disguise, for the aging beauty queen is transformed into a hideous, grotesque much older woman. The ugliness of her disguise mirrors her 
fatal obsession with youth and beauty. Her evil nature is, moreover, highlighted by the similarities between her action and the biblical image of the fatal fruit offered to Eve by the serpent.

In Grimm's narrative, the queen dies when she literally “choked with rage”. Thus, death becomes the very essence of evil, not respected as an inevitable part of life (Caputi, 2004, p. 318). At the end of the movie, on the other hand, the wicked queen is destroyed by Snow White, her prince and the dwarfs; "Love, beauty, and youth conquer all” (Perry, 1999, p. 204), and the audience can subconsciously understand her insecurities when it comes to the female loss of beauty and youth. In addition,

Like the stepmother, many women perceive others as more attractive than themselves and feel envy, rage, and even violence toward one another. Good looking women, regardless of their other attributes, are just more competition for the few Princes out there... When they felt they didn't measure up to the competition, their anger, resentment, and even evil thoughts rivaled those of the wicked Queen. (Hesse-Biber, 1997, p. 74)

A tremendous success in both artistic and commercial terms, Snow White would determine the studio's future direction (Kaufman, 1993, p. 172). Thus, Disney's successful formula of incorporating patriarchy into classic fairy tales by eliminating or down-playing, female characters' self-empowerment and foregrounding male power in its first animated film will be used in most of their consecutive animated films.

\section{Cinderella}

Another Disney film where an aging wicked stepmother is portrayed is Cinderella based on Charles Perrault's Cinderilla; or, The Little Glass Slipper, a tamer and less gory version than Grimms' version with its dismembered body parts and pecked out eyes (Clarke, 2000, pp. 698-699). Cinderella's stepmother, Lady Tremaine, is described as bitterly jealous of her step-daughter's charm and beauty in comparison to her own fading youth. As for the father, in order not to focus on his wrongdoing and irresponsibility toward his daughter, he is killed in the Disney adaptation. In the movie, the stepmother's cat is significantly named Lucifer, an alter-ego that demonstrates the same mean qualities of his mistress, a vindictive villainess. Furthermore, Lady Tremaine has exaggerated long, bony fingers with nails clearly defined in close-ups, and emphasized lower teeth which "link her anatomically to the only other character with emphasized nails, Lucifer the cat, who is also her bedmate... She represents the anti-family... Most of her interactions with her family are commands" (O’Brien, 1994, p. 67).

Since caring for older family members is usually considered low status and usually ends up creating unresolved tension between the caretaker and his/her filial responsibilities and feelings of anger, frustration and resentment (Cruikshank, 2009, pp. 124-128), viewers could grasp the escalating situation between Cinderella and her family from the very beginning of the film. Not only does Lady Tremaine punish Cinderella and force her to do all the household chores, she is also shown as a harsh mother to her two natural daughters, Anastasia and Drizella. Although another aging female character, the fairy godmother, is portrayed as the total opposite, her brief appearances-in comparison to the major role played by the stepmother-together with that of the aging King only act as foils to the wicked stepmother. Typically, the film ends with Cinderella and the prince kissing each other in their wedding carriage.

One of the questions nowadays audience ask themselves is whether the Cinderella tale reinforces negative stereotypes of women or not. Are passivity, victimization, feminine charm, and physical beauty the necessary precursors to marriage and fortune? Disney's Cinderella is "an innocent, insipid, too-good girl... [who] has no real, direct involvement in bringing about her own good fortune” (Linder, 2001, p. 35). She signifies the 
importance and the sacredness of women's role and work, mainly housework, and her ideal is exemplified in the Disney song, "Some Day My Prince Will Come”. In 1981, Colette Dowling would coin the term "Cinderella Complex" to describe the female fear of success and her incapability to change her situation without help by an outside force, usually a male (represented by the prince in the fairy tale). On the other hand, the male-centered stepmother is in constant competition with other women for the sake of male approval and, ultimately, idleness ("When you are Queen you will not have to walk"). Thus, based on the Cinderella tale, women have three choices: First, to become ruthlessly competitive and pettily cruel; secondly, to be swallowed by a patriarchal world that does not value them; thirdly, to believe that loving service brings joy and to wait for divine help (Clarke, 2000, pp. 698-707). Marlate-Feldman argues that Disney's manipulation and americanization of Perrault's text, making Cinderella an "All American Girl... a girl who sings her heart out while awaiting the arrival of her prince" conforms to the "safe fantasies of Consumer Romance" and to the "conservative and anti intellectual ideology" in the 50s, missing "the primordial function of the tale, which is not to find Prince Charming, but to find one's self” (Marlate-Feldman, 1999, pp. 193-194). Although Cinderella supposedly wins the prince as a reward for her long-suffering patience and innate goodness, Panttaja argues that battling for the prince's attention is won because of her stunning dress, disobeying her stepmother, using magic powers, lies, and disguise (Panttaja, 1993, pp. 90-91).

In the fairy tale, the "wicked" stepmother is only mentioned at the beginning of the story when introducing Cinderella's life at home. Moreover, the two step-sisters show remorse at the end and they are given the chance to marry well and live in the palace with the new princess. Not only this, but in the fairy tale also, the stepmother and step-sisters are beautiful in countenance, but ugly on the inside (Linder, 2001, p. 36). On the other hand, in the Disney film, they are "coarse, petty, and ambitious, empty of the innate grace that marks the gentility" (Panttaja, 1993, p. 94), and they are physically homely, clumsy, and comical; the grotesqueness of their physicality is emphasized by their big rears, exaggerated large feet and big toes, clumsy big hands, and non-existent breasts, making the young viewer miss the subliminal message that one should be cautious of the destructiveness of selfishness, superiority, and lack of compassion (Linder, 2001, p. 37).

Unlike the Grimm's version, Disney trivializes the mother figure; the film lacks any reference at all to the good mother and her death. Even the fairy godmother is given more space in the fairy tale text, appearing at the end of it to give Cinderella another "cloaths, made richer and magnificent than any of those she had before”. In the Disney version, however, the appearance of the fairy godmother is minimized and she merely appears as a magical wish granter, like a genie. She "does not play any role in the story's moral or thematic needs; it works more or less as a mere plot mechanism, a way of getting Cinderella to the ball so that she can meet and marry the prince” (Panttaja, 1993, p. 102). In addition, her absent-mindedness and physical appearance (short stature, weak chin, and chubbiness) soften her role as a powerful female. She only functions as a surrogate mother to Cinderella and a restrainer, setting time limits (O’Brien, 1994, p. 74). Moreover, the film focuses on the stepmother, highlighting the relationship between aging and evil, showing her irrevocable negative effect on her two daughters, the "evil step-sisters". According to Perrault (2009), the moral of the story is that:

Beauty's to the sex a treasure, Still admir'd beyond all measure, And never yet was any known, By still admiring, weary grown. But that rare quality call’d grace, Exceeds, by far, a handsome face; Its lasting charms surpass the other.

To Cruikshank, old people’s oppression and powerlessness are demonstrated by “obsessive self-concern, passivity, clowning, fear of aging, and failure to identify themselves as old” (Cruikshank, 2009, p. 4), and the 
state of widowhood only increases their poverty risk (Cruikshank, 2009, pp. 115-116). Lady Tremaine, consequently, could be considered a classic example of a woman fighting such social stigmas. Although she has no magical powers, in the Disney film, she is a manipulative, cold, cruel, and sadistic gold digger, who, beneath her calm exterior, is always plotting to advance her social status through her two daughters. If one forgoes Disney's interpretation of Lady Tremaine's character, one might start to sympathize with her or, at least, start to understand her motives. Living in a patriarchal society where young women are either servants or ladies looking for a rich husband, she is a struggling widow, a single mother who has to launch two daughters in the marriage mart, therefore, exaggerating her caricatured persona only highlights the difficult position she is in. Thus, what the stepmother really aspires to is long-term goals; she is devoted to her daughters and wants to ensure a future of power and prestige for them, and she is willing to resort to extreme measures to achieve her aim.

\section{Sleeping Beauty}

In early 1959, Walt Disney released Sleeping Beauty, an animated musical fantasy based on the Brothers Grimm's Little Briar Rose and Perrault La Belle au bois dormant. Compared to earlier Disney princesses, Aurora plays a minimal role, with many scenes depicting her crying, sleeping, and not even trying to defend her love. With such a character that exemplifies female passivity, one wonders whether the prince in Sleeping Beauty falls in love with Aurora while she is asleep or because she is asleep (Caputi, 2004, p. 330). Gender and age are two important markers of social difference, and in Disney's Sleeping Beauty, old people could be categorized into three different groups. The first group consists of King Stefan, his queen, and King Hubert, three characters of whom we know scarcely nothing. Comparing Aurora's parents at the beginning and at the end of the film shows the audience that they do not physically age, hinting at the fact that goodness is equated with agelessness. Again, the good old mothers are marginalized, with one queen not given a name and excluded from many scenes and the second—Philips' mother—not even mentioned. Even the two passive kings play a minimal role and they are depicted as big children who spend their time playing with their food while jesting with each other instead of running their kingdoms. The second group consists of the three good fairies. Described as "poor simple fools", they are given the role of grandmothers, the caretakers of children. The kindly, yet ineffectual, fairies are fat and short. They are the keepers of traditions, symbolized by their eating and drinking habits (biscuits and tea). More importantly, being less powerful than Maleficent, they have to join forces with a male-Prince Phillip-in order to defeat the former. The third group consists of Maleficent, the malevolent fairy who bears the title of "Mistress of all evil". When it comes to analyzing the body image of Maleficent, one should remember that the film was first released in the late fifties, an age that idolized Marilyn Monroe’s bosomy beauty (Hesse-Biber, 1997, p. 4), consequently, the extremely slimmer and much less curvaceous body of the evil fairy would have repulsed the audience back then. On the other hand, the three good fairies remind us of Cinderella's fairy godmother: short and plumb. Black color symbolism also aids in highlighting the evilness of the queen (besides all the social, ethnic and racist connotations). Opposite to the fair Aurora who wears pastel colors, the wicked queen is featured dressed in black, living in a black castle that has black rats, surrounded by a dangerous black forest containing black bats and owls. Moreover, she has a black crow-like bird—Diablo—and the end of the film implies her being devoured by black vultures (Hurley, 2005, p. 224).

In May 2014, Disney released Maleficent, a live-action re-imagining of Disney’s animated 1959 Sleeping 
Beauty. But why dig out an iconic villain 55 years after its introduction in cartoons? Is it an attempt by Disney to revitalize their franchises, drawing on established fan bases who are still passionate about films they grew up with? Or is it, like screenwriter Linda Woolverton says, due to "such a lack of great material out there they're mining it for everything they’ve got out of desperation?” (as cited in Keegan, 2014). No matter what the real motive is, Maleficent definitely represents Disney's changing tide that began with Princess Merida in Brave (2012) and led into the phenomenon that is Frozen (2013): The line between villain and hero has blurred. Moreover, with Maleficent, Disney is building a new fan base of those who sidestepped the princess phase and are looking for an alternative to traditional fairy-tale heroines. Starring Angelina Jolie as the eponymous villainess, the film portrays the story from the perspective of the antagonist (through an elderly Aurora), giving her the opportunity to tell her own experience of events, and encouraging the audience to identify with her. By providing motivation and context for her actions, and questioning the traditional interpretations of her choices, it is difficult to simply characterize her as wicked. This, consequently, leaves the audience with an important question: Who is the real villain of the story? Moreover, aging and villainy are treated differently in Maleficent. By presenting the audience with an actress considered a sex icon, Disney finally annihilates the relation between women and evil, old age, and ugliness. Neither Maleficent nor the three good fairies (whose screen times are minimized and characters trivialized) seem to age in the film, reinforcing the traditional message of their inner goodness. Accordingly, instead of the expected demonization of female (strong) figures, masculinity becomes the true villain in Maleficent in which complex, strong females are dominant (Wilson, 2014). It is King Stefan whose aging process is accompanied by a descent into madness. In Maleficent, although the evil fairy keeps her traditional look (black clothes and devilish horns), she is more of a hero, and it is her "true love's kiss" and not the prince's that awakens Aurora. At the end, Aurora fittingly notes in voiceover, "My kingdom was united by one... who was both hero and villain”. Unlike traditional villainesses, Maleficent has the potential for redemption.

\section{The Little Mermaid}

After 30 years of absence, Disney would produce a new animated fairy tale in 1989 whose critical and commercial success would start a popular renewed interest in Disney animation. Like Snow White and Cinderella, The Little Mermaid, based on Hans Christian Andersen's text, continues the formula of princess and prince versus the evil old woman (stepmother and/or witch). Of course, having legs in the Disney version is a joyful experience unlike in Andersen's version where "every step... [feels like] trading upon sharp knives, and... the blood must flow"; an acceptable price for not only a pair of legs but also for an immortal soul. Furthermore, the loss of voice in the fairy tale is a result of the gruesome cutting off of Ariel's tongue as payment (a detail not fit for the young audience and omitted in the film). Another disturbing detail thankfully omitted from the film is the fact that Ariel stayed with the prince more of a slave or a "foundling" than a guest, for she "received permission to sleep at his door, on a velvet cushion. He had a page's dress made for her, that she might accompany him on horseback”. However, the price of Ariel's adventure is the same in both versions: If Ariel fails to get Prince Erik to kiss her in three days, she must return to the sea and become Ursula's slave. Like all typical Disney villainesses, Ursula lives with two devilish pets, the eels Flotsam and Jetsam. From this point onwards, each of the two versions of The Little Mermaid drifts apart. In Andersen's fairy tale, while Prince Erik is getting ready to marry a beautiful princess from a neighboring kingdom, Ariel's last chance of survival is plunging a dagger in her prince's heart in order to survive and go back to being a mermaid. When 
she selflessly refuses to do so, she is saved by the "daughters of the air"; Ariel loses her love and her prince but she gains an immortal soul. On the other hand, and similar to the evil queen in Snow White, Disney's Ursula is portrayed as an old woman obsessed with youth and beauty. Thus, not only does she use Ariel's melodious voice as her own, but she transforms herself into a beautiful princess, a replica of Ariel, in an attempt to trick to the prince to marry her. Such strategy of trying to look younger masks the fear of the label "old" which in itself has become a reference to "decline” (Cruikshank, 2009, p. 199). After being saved by Ariel's non-human friends-Flounder the tropical fish and Sebastian the crab-both Ariel and Erik enter a glorious battle against the power-hungry Ursula, who not only strives for youth and beauty but also for usurping the Sea King and becoming the queen. Ursula's brief success to seize King Triton's crown and scepter and her growing to gigantic, fearsome proportions is accompanied by her reciting, "I am the ruler of all the oceans. The waves obey my every whim. The sea and all its spoils bow to my power”. Given the patriarchal context of the film/story, her words could be considered heresy, punishable by death (Caputi, 2004, pp. 321-322). Like the evil queen in Snow White, Ursula is killed at the end and the young lovers are given the chance to live happily ever after. Caputi argues that Ursula is an unmistakable avatar of the water goddess figure (known as "Mammy Water" in Africa and "Water Monarch" or "Erzulie" in the Americas) who lives at the bottom of deep waters and holds power over life, death, and destiny and is frequently worshipped by women who refuse to lead conventional lives, consequently, her death scene symbolically suggests "rape-murder" (Caputi, 2004, p. 321).

When compared to the evil queen in Snow White and the wicked stepmother in Cinderella, Disney's Ursula could be seen as one of the most hideous aging females. Although the description of the sea witch in the fairy tale is limited to how she allows "a toad to eat from her mouth... [calling] the ugly water-snakes her little chickens, and allowed them to crawl all over her bosom”, in the Disney film, Ursula's disgustingly obese female form, whose upper body is that of a Sumo wrestler and lower body of a frightening octopus is contrasted with Ariel's delicate auburn-haired beauty. Ursula's hair is wild and white (another indicator of old age), her lips are large and red, her skin is purplish, and her voice is masculine. Ursula, therefore, represents the power-hungry stereotype, in contrast to the wise and kind Sea King who, despite his old age (represented in his long white hair and beard) is still physically fit and handsome. Such hunger for power could be viewed as a desperate attempt to regain what power the witch lost together with her youth. Physically, Ursula's old age is reflected in her obese body that stands in open contrast to Ariel's slim physique. By associating weight with evil (in one scene, Ursula's huge breasts fill the entire screen), Ursula's grabbing tentacles and manipulative personality reflect Disney's characterization of older women as huge predatory villains.

While Andersen's sea was nearly a matriarchy (with a queen mother, a king, and many princesses), Disney's world only shows the negative side of feminine rule and the positive side of masculine rule. With the destruction of the sea witch, the beings of the sea can finally live happily ever after under the rule of the "male" monarch; Disney definitely prefers a patriarchy more than a matriarchy (Dahlerup et al., 1991, pp. 151-152). Not only is a patriarchal kingdom preferred, but aging women are also targeted by Disney. According to Chivers, men and women experience age differently depending on how they construct their self-worth; "Old women are perceived to experience at least twofold cultural loss because it is not just their utility but also their femininity that is considered to fade" (Chivers, 2003, p. xv). What pushes Ursula's age under the spotlight, therefore, is the fact that in Disney's version of the story, the character of the Sea King's "aged mother" is omitted. The "very wise... exceedingly proud" grandmother in Andersen's fairy tale is erased in the movie so that the viewers are only left with a negative example of an aging female. As for Ariel, although some might 
see her as a typical Disney princess who gives up her life with her family for a man, one can argue that, despite her silence for a good portion of the film, she is the first princess to have opinions, flaws, and interests, and her choice of becoming human only shows how much she wants to change her life.

\section{Tangled}

Compared to Grimm's version of Rapunzel, Disney’s 2010 Tangled shows a far more assertive character whose magical hair can be used to heal or restore youth in others. Besides sewing and baking, Rapunzel is shown reading, doing astronomy (her chameleon is named Pascal after the mathematician), painting, fighting with a frying pan, and strategically deciding to reach her goal of seeing the flying lanterns on her birthday. The film's premise is even centered around the idea that women should not spend their whole lives at home.

Tangled... takes the traditional fairy tale of Rapunzel and alters it to challenge the stereotypical gender role of a princess... Disney's choice to put romance as second to Rapunzel's desire to leave the tower and gain independence illustrates a step in the right direction towards challenging the female social norm which was depicted early in the film when she is seen cleaning, painting, cooking, doing arts and craft, dancing, and baking. (King, 2013)

Disney also elevates Rapunzel's social status, making her join his fleet of princesses while replacing Rapunzel's rescuer with a handsome yet self-interested thief. By saving him multiple times along the way, Rapunzel shows that the era of the helpless damsel in distress is over. On the other hand, although she does not need to clean up after a bunch of men (like Snow White), she is forced to clean up men's messes, especially those of Flynn Rider. In addition, though Rapunzel seems a strong, self-sufficient character capable of taking care of herself, she still needs the introduction of a handsome man in her life before she is set free.

Like most Disney animated films, Tangled features two opposing views of aging. On the one hand, the audience are presented with Aurora's parents, the king and queen, whose role is minimalist, who do not appear to be physically aging, and who exemplify the stereotype that old people are lonely or isolated (Cruikshank, 2009, p. 200). On the other hand, in Tangled, Disney keeps his earlier policy of creating old villainesses, although mother Gothel's motivation for villainy is neither power nor revenge; she is fixated on eternal youth. To absolve Rapunzel's parents from any wrong doing and cement Gothel's role as the evil enchantress, Rapunzel is kidnapped instead of being given up for the sake of an unstoppable craving of the forbidden rampion. Although Disney tries to make captivity look fun, it is difficult for the audience to acknowledge such solitary confinement. Following the model of the evil queen in Cinderella and Ursula in The Little Mermaid, Gothel is obsessed with physical beauty and eternal youth. Giving her a dress from the Renaissance-which is 400 years before the time period of when the film takes place in the 1780s—only emphasizes how Gothel and Rapunzel do not match up and how long Gothel has been living. Moreover, she is passive, aggressive, manipulative, vain, and arrogant, and she masks her villainy in the guise of love. Despite her attempts to be "mother" Gothel (reminding us of lady Tremaine, a fake motherly figure to the beautiful Cinderella), her refusal to communicate with Rapunzel along with her passive and demeaning comments toward the latter are anything but nurturing. She, moreover, often cruelly teases Rapunzel and guilt-trips her whenever the latter is upset or disappointed, dramatically proclaiming, "now I'm the bad guy”. Gothel is pushed further and further into the role of villainess as Rapunzel grows close to Flynn Rider and begins discovering her true identity. She is driven to the point where she is willing to commit murder, with no remorse, just to retain her youth for all eternity. Significantly enough, Flynn cuts off Rapunzel's hair at the end with a shard of glass from a broken mirror, a reminder of the magic mirror in Snow White and the evil queen's similar quest of everlasting beauty. 
When Rapunzel's hair turns into its normal brown, Gothel staggers back as her skin begins to wrinkle. Horrified by her reflection, she trips over some of Rapunzel's cut hair and falls out the window. By the time her cloak hits the ground, she has rapidly aged into a pile of ashes.

\section{Frozen}

In 2013, Walt Disney released its 53rd animated feature film: the 3D musical Frozen, inspired by Andersen's 1844 fairy tale The Snow Queen, which has recently become the fifth highest-grossing film of all time (Muhanna, 2014). The film's success is thought by many critics to mark a Disney Renaissance due to its visuals, themes, musical numbers, screenplay, and voice action. Frozen, however, exemplifies a major change in Disney traditions, mainly because of the (non-)choice of villain. At the end of the film, when Prince Hans of the Southern Isles should be saving Princess Anna, he reveals himself to be a greedy, throne-usurping would-be killer, and instead of kissing her, he sneers, "Oh, Anna, if only there were someone who loved you". However, there are two major differences between Disney villainesses and Prince Hans: First, he is a handsome young man with whom the audience can identify (and even forgive). Secondly, unlike the gruesome endings Disney villainesses usually face, Prince Hans is only kicked out of Arendelle and sent back home to face punishment for his crimes against the royal family of Arendelle; he is treated more like a naughty child than a villain. As for the Duke of Weselton, an older man who tries to exploit Arendelle for profit, he is manipulative and greedy though not a real villain, and his punishment is cutting off trade with him. The most controversial character is Queen Elsa, the heroine/villainess of Frozen. One of the turning points in the film is when the ostracized Queen Elsa, who abandons her kingdom when her magical ability gets out of control and is discovered by the public, sings "Let it Go". The Oscar winning song is about liberation, empowerment, and celebrating the release for those who have been living in fear or bondage. It is also about tragedy, anger, bitterness and despair (“Oh, I’m such a fool, I can't be free/No escape from this storm inside of me”). Although Elsa temporarily loses her sense of right and wrong ("No right, no wrong, no rules for me"), she does not turn evil, although in one scene, heroic Princess Anna faces destruction by the snowman-monster, an agent of her sister, Elsa, herself. The song, therefore, shows her precarious position and makes the audience question the possibility of her being a villain. "Let It Go", thus, informs the audience of the evil and the despair that Elsa has the potential to fall into, while keeping her a completely sympathetic character. When compared to Andersen's The Snow Queen, good and evil are not easily identified in Frozen. The title character of the original fairy tale was evil, but her 21st-century descendant is merely confused and scared and not just an object of desire. One might even see Elsa as an icy figure in need of taming by her kinder, more traditionally feminine sister. In Frozen, "cold" is not just a temperature, it is an isolation from other people, and it takes sisterly loyalty, devotion, solidarity and selfless love-rather than romantic attachment- to thaw Elsa's icy heart.

There is no doubt that Frozen illustrates Disney's transformation towards a more 21st-century story. Instead of focusing on the love triangle, and the healing qualities of a prince's kiss, the story of the film revolves around sisterly love and solidarity, though still featuring the theme of sacrifice commonly found within Disney. Instead of ending with a wedding, Frozen does not end in marriage and Elsa becomes the sole ruler of the kingdom and not just an accessorial Disney princess. The film also forgoes the Disney tradition of gendering evil, and old people are excluded from the major storyline (even the girls' parents-who have controversial influence on their kids - die at shipwreck during a storm when the former were teenagers). As for Anna's hair turning white, it is an indication of her failing health and partially frozen heart and not symbolic of old age. 
Mainly perceived as a girl's brand, Disney has been lately changing its marketing strategies aiming at expanding into boys' culture. In 2009, Disney hired Kelly Peña—called the "kid whisperer" by some Hollywood producers - to "unearth what makes... [boys] tick and use the findings to help the Walt Disney Company reassert itself as a cultural force among boys” and the effects of her scrutiny could be seen on Disney XD cable channel and web site (Barnes, 2009). The company also purchased Marvel Entertainment Inc. in 2009, appealing to boys with more than 5000 macho superhero types. In 2013, the shrewdly deceptive marketing campaign of Frozen avoided the slightest suggestion that the film is either a musical or about princesses and queens. The billboards showed four human principals (two males and two females) covered in snow while giving pride of place to the comic-relief figure, Olaf the snowman. In addition, the film carries a gender-neutral title (similar to the choice of "Tangled" instead of "Rapunzel”) to suppress anything remotely girly about it. The commercial success of such a campaign is evident: The film accumulated over 1.2 billion dollars in worldwide box office revenue. However, unlike most previous Disney films, most viewers seem not to notice that Frozen is (loosely) based on a fairy tale, making Disney look like its sole author. Such a belief has been more solidified after the airing of Season Four of the fairy tale drama series Once Upon a Time in Fall 2014, casting Frozen characters primarily based on the Disney version and not the fairy tale.

\section{Conclusion}

From its beginnings as a small studio in the 1920s, the Disney Company has become one of the most influential organizations in the world of entertainment. No wonder then that its visual representations have increasingly come to dominate fairy tales. Disney films, therefore, should not be viewed as a mere "Hollywoodized or Disneyfied version" of fairy tales, for they become the only version that many children ever experience, providing them with role models that are crucial to the development of their own identities (Booker, 2010, pp. 3-4). Although both men and women are capable of turning into villains, it is usually women, especially the older ones, who are branded as evil villainesses in many of Disney's works. While the heroine is usually noble and attractive by birth, villainesses are portrayed as unattractive, semi-elite social misfits that try to disrupt the social order, and if they attain power, their reign is disastrous and temporary (Artz, 2011, p. 385). Thus, due to ideological and commercial reasons, most of the female characters are deleted from the original classic fairy tale texts with the exception of the protagonist (young and good) and the antagonist (old and evil). Disney is definitely not a harmless TV/DVD babysitter for children.

In five out of the six chosen Disney animated feature-length films, an aging female character exhibits stereotypical behaviors traditionally associated with aging. According to Perry (1999), "By continually depicting aging as negative, the media creates a society that denies and mistrusts all persons who are past their youth” (p. 209). Such depiction shows how society values youthful beauty in women, consequently, when such beauty is lost and those women try to compensate it with power, villainesses are born. We, the audience in general and parents in particular, need to acknowledge mature beauty in women. We need heroines who not only possess intelligence and are not just desperately waiting to be rescued by a handsome prince, but who are also not afraid of aging. In our current societies where the ranks of aged grow with each passing day, we have an obligation to our children to present them with an affirmative view of the aging process. More importantly, we need to avoid sexist views of aging; we need more positive mature female role models. Disney, with all its culturally conditioning force, should aid in this endeavor and not maintain traditional gender, age, and power hierarchies. 


\section{References}

Andersen, H. C. (2008). The little mermaid. Retrieved from http://www.gutenberg.org/files/27200/27200-h/27200-h.htm

Andersen, H. C. (2013). The snow queen. Retrieved from http://www.andersen.sdu.dk/vaerk/hersholt/TheSnowQueen_e.html

Artz, L. (2011). Monarchs, monsters, and multiculturalism: Disney’s menu for global hierarchy. In G. Dines, \& J. M. Humez (Eds.), Gender, Race, and Class in Media: A Critical Reader (pp. 383-388). USA: SAGE Publications.

Barnes, B. (2009). Disney expert uses science to draw boy viewers. Retrieved from http://www.nytimes.com/2009/04/14/arts/television/14boys.html?pagewanted=all\&_r=0

Booker, M. K. (2010). Disney does America: A political history of children’s film. In Disney, Pixar, and the Hidden Messages of Children's Films (pp. 1-36). California: Greenwood.

Buck, C., \& Lee, J. (2013). Frozen [Film]. California: Walt Disney.

Calasanti, T., Slevin, K. F., \& King, N. (2006). Ageism and feminism: From 'Et Cetera’ to Center. NWSA Journal, 18(1), 13-30.

Caputi, J. (2004). Goddesses and monsters: Women, myth, power and popular culture. Wisconsin: Wisconsin UP.

Chivers, S. (2003). From old woman to older women: Contemporary culture and women's narratives. Ohio: Ohio State University.

Clarke, M. M. (2000). Jane Eyre and the Grimms' Cinderella: Studies in English literature 1500-1900. The Nineteenth Century, 40(4), 695-710.

Clements, R., \& Musker, J. (1989). The Little Mermaid [Film]. California: Walt Disney.

Cottrell, W., Jackson, W., Morey, L., Pearce, P., \& Sharpsteen, B. (1937). Snow White and the Seven Dwarfs [Film]. California: Walt Disney.

Cruikshank, M. (2009). Learning to be old: Gender, culture and aging. USA: Rowman \& Littlefield Publishers.

Dahlerup, P., Thomsen, U., Soracco, S. L., Ingwersen, N., Ingwersen, F., Nybo, G., \& Dahlerup, P. (1991). Splash! Six views of the little mermaid [Corrected Version]. Scandinavian Studies, 63(2), 140-163.

Deats, S. M., \& Lenker, L. T. (1999). Introduction. Aging and Identity: A Humanities Perspective (pp. 1-20). USA: Praeger Publishers.

Deszez, J. (2002). Beyond the Disney Spell, or Escape into Pantoland. Folklore, 113(1), 83-91.

Doherty, T. (2006). The wonderful world of Disney studies. Retrieved from http://chronicle.com/article/The-Wonderful-World-of-Disn/9806/

Dowling, $\quad$ C. (1981). The Cinderella Syndrome. $\quad$ Retrieved from http://www.nytimes.com/1981/03/22/magazine/the-cinderella-syndrome.html

Faurholt, G. (2009). Self as other: The Doppelgänger. Retrieved from http://www.doubledialogues.com/issue_ten/faurholt.html

Geronimi, C., Clark, L., Larson, E., \& Reitherman, W. (1959). Sleeping Beauty [Film]. California: Walt Disney.

Geronimi, C., Luske, H., \& Jackson, W. (1950). Cinderella [Film]. California: Walt Disney.

Giroux, H. A. (2011). How Disney magic and the corporate media shape youth identity in the digital age. Retrieved from http://www.truth-out.org/opinion/item/2808:how-disney-magic-and-the-corporate-media-shape-youth-identity-in-the-digital -age

Greno, N., \& Howard, B. (2010). Tangled [Film]. California: Walt Disney.

Grimm, J., \& Grimm, W. (2004). Rapunzel. Retrieved from http://www.gutenberg.org/files/2591/2591-h/2591-h.htm

Grimm, J., \& Grimm, W. (2012). Snowdrop. Retrieved from http://www.gutenberg.org/files/2591/2591-h/2591-h.htm

Hannon, C. J. (1997). Aging with Disney: Depiction of gender and age in seven Disney animated fairy tales (Ph.D. diss. Oklahoma University).

Hesse-Biber, S. (1997). Am I thin enough yet? The cult of thinness and the commercialization of identity. USA: Oxford UP.

Hurley, D. L. (2005). Seeing white: Children of color and the Disney fairy tale princess. The Journal of Negro Education, 74(3), 221-232.

Kaufman, J. B. (1993). Before snow white. Film History. Spec. issue of Animation, 5(2), 158-175.

Keegan, R. (2014). Maleficent and why we love our childhood villains. Retrieved from http://www.latimes.com/entertainment/movies/la-et-mn-maleficent-villains-20140530-story.html\#page=1

King, R. (2013). Disney's Tangled and challenging the princess stereotype. Retrieved from http://huskiesinwonderland.wordpress.com/2013/04/05/disneys-tangled-and-challenging-the-princess-stereotype-ryan-king/

Laderman, G. (2000). The Disney way of death. Journal of the American Academy of Religion, 68(1), 27-46. 
Linder, L. L. (2001). Comparison of various Cinderella stories from the Jungian perspective. The San Francisco Jung Institute Library Journal, 20(3), 33-44.

Luscombe, B. (2012). Q\&A with P90X Creator and Fitness Guru Tony Horton. Retrieved from http://healthland.time.com/2012/08/30/qa-with-p90x-creator-and-fitness-guru-tony-horton/

Marlate-Feldman, C. (1999). The challenges of translating Perrault’s 'Contes’ into English. Marvels \& Tales, 13(2), 18-198.

Moody, H. R. (2006). Basic concepts I: A life course perspective on aging (5th ed.), Aging Concepts and Controversies (pp. 1-26). USA: Pine Forge Press.

Muhanna, E. (2014). Translating Frozen Into Arabic. Retrieved from http://www.newyorker.com/online/blogs/books/2014/05/translating-frozen-into-arabic.html?mobify=0

O’Brien, S. R. (1994). Disney’s Cinderella under cover: Heads, butts, toes, and gender woes. Studies in American Humor, 3(1), 62-79.

Panttaja, E. (1993). Going up in the world-class in Cinderella. Western Folklore. Perspectives on the Innocent Persecuted Heroine in Fairy Tales, 52(1), 85-104.

Perrault, C. (2009). Cinderilla; or, The Little Glass Slipper. Retrieved from http://www.gutenberg.org/files/29021/29021-h/29021-h.htm\#Cinderilla_or_The_Little_Glass_Slipper

Perry, M. G. (1999). Animated Gerontophobia: Ageism, Sexism, and the Disney Villainess. In S. M. Deats, \& L. T. Lenker (Eds.), Aging and identity: A humanities perspective (pp. 201-12). USA: Praeger Publishers.

Solis, S. (2007). Snow White and Seven 'Dwarfs'-Queercripped. Hypatia. Writing Against Heterosexism, 22(1), 114-131.

Strombert, R. (2014). Disney’s Maleficent [Film]. California: Walt Disney.

Wilson, N. (2014). Maleficent: Finally, Disney gives us a positive witch/mother. Retrieved from http://msmagazine.com/blog/2014/06/02/maleficent-finally-disney-gives-us-a-positive-witchmother/

Wohlwend, K. E. (2009). Damsels in discourse: Girls consuming and producing identity texts through Disney princess play. Reading Research Quarterly, 44(1), 57-83.

Woodwind, K. (1999). Introduction. Figuring Age: Women, Bodies, Generations (pp. ix-xxix). Indiana: Indiana UP. 